\title{
Two new species of the genus Phronia Winnertz (Diptera: Mycetophilidae) from Finland and Russian Karelia
}

\author{
Jevgeni Jakovlev \& Alexei Polevoi
}

Jakovlev, J. \& Polevoi, A. 2008: Two new species of the genus Phronia Winnertz (Diptera: Mycetophilidae) from Finland and Russian Karelia. — Entomol. Fennica 19: 199-206.

Phronia avidoides sp.n. and Phronia fennica sp.n. are described based on several adult males collected by Malaise trapping, sweep-netting and rearing from decaying wood in Finland and Russian Karelia in the period 1989-2005. Detailed illustrations of male terminalia are also presented for three further closely related but poorly known species, Phronia avida Gagne, 1975, Phronia petulans Dziedzicki, 1889 and Phronia subsilvatica Hackman, 1970.

J. Jakovlev, Finnish Forest Research Institute, Vantaa Research Centre. P.O. Box 18, FI-01301, Vantaa, Finland; E-mail: jevgeni.jakovlev@metla.fi

A. Polevoi, Forest Research Institute, RU-185910, Pushkinskaya 11, Petrozavodsk, Russia; E-mail: alexei.polevoi@krc.karelia.ru

Received 10 July 2007, accepted 1 November 2007

\section{Introduction}

The genus Phronia Winnertz, 1863 is one of the largest genera of Mycetophilidae. It is best known in the Holarctic region, including nearly $85 \mathrm{~Pa}$ laearctic and 50 Nearctic species, while rather few species are known from the other biogeographic regions (Bechev 2000). The recognition of the first species of the genus dates back to the middle of the 1800s. H. Dziedzicki (1889) published the first comprehensive monograph on Phronia. This excellently illustrated work included 51 European species (some of them are now transferred to the genus Trichonta Winnertz, 1863), of which 33 were described as new. Gagné (1975) presented a revision of the Nearctic species of Phronia, and Plassmann (1977) revised the European fauna. After these comprehensive studies only a few species have been described from Europe (Chandler 1992, Chandler \& Ribeiro 1995, Zaitzev \& Polevoi 1995, Plassmann
1999), increasing the number of recognized species known from Europe to 65 (Chandler 2005). Altogether 60 species are recorded from the Nordic region where the fauna of Phronia is fairly well known. The level of faunal knowledge of Phronia is particularly good in Finland owing to the contribution made by Lundström (1906, 1909, 1911, 1914) and especially Hackman (1970), who recognized 54 species of Phronia, including eleven newly described species. Two further species, $P$. gagnei Chandler, 1992 and $P$. coritanica Chandler, 1992 were added to the Finnish fauna by Polevoi (1995) and Kurina (2003), respectively. Including the two new species presented here, 58 species are currently recorded from Finland, 49 from Sweden (Kjærandsen et al. 2007), 39 from Russian Karelia (Polevoi 2000) and 39 from Norway (Gammelmo \& Søli 2006).

Larval biology of Phronia is poorly known. Generally, the larvae are saproxylic, associated 
with dead wood and wood-growing fungi. Since Phronia larvae are not common inhabitants of fungal fruiting bodies, fungal hosts have been recorded for few species only (Chandler 1978, Jakovlev 1994). Unlike most other Mycetophilinae that usually develop inside fungal fruiting bodies or under bark, Phronia species have casebearing larvae which are protected by slime and able to live on the surface of encrusting fungi growing on decaying wood, or on moulds growing on fallen, wet and barkless branches.

\section{Material and methods}

During the treatment of a large material of ca. 100,000 specimens of fungus gnats collected in Finland and Russian Karelia in the years 19892005 (for details see Polevoi et al. 2006, Jakovlev et al. 2006) we have found two new species of Phronia. Additional records of species new to Finland were obtained by reviewing selected parts of the collections of the Zoological Museum of Helsinki University (Museum Zoologicum Helsingiensis, MZH) and Forest Research Institute of Karelian Scientific Centre, Petrozavodsk, Russia (FRIP).

The holotypes and paratypes of the new species are dry-pinned. Terminalia were treated in a standard way (heating in a solution of $\mathrm{KOH}$, neutralization in acetic acid, washing in distilled water) and preserved as glycerine preparations in small vials on the same pin as the rest of the body. Other specimens studied are kept pinned or in ethanol. Material is stored in MZH, in FRIP, in Finnish Forest Research Institute, Vantaa, Finland (METLA), in Natural History Museum of Central Finland (NHMCF) and in personal collection of Jouni Penttinen (JP).

The structure of the records presented below is: number of males studied, code for biogeographical province (Heikinheimo \& Raatikainen 1971), municipality, location, date and collector. For new records from Finland we present coordinates according to the Finnish national grid coordinate system. Collecting method (if not specified elsewhere) is Malaise trapping. Detailed information on the collecting localities for each species is given separately. The morphological terminology follows Søli (1997).

\section{Description of species}

\subsection{Phronia avidoides sp. n. (Fig. 1)}

Type material. Holotype $\widehat{\jmath}$, Finland, Ta: Lammi, Kotinen strict nature reserve, 6794400: 3396400, 28.VIII.-4.X.2004, Jakovlev leg (MZH). Paratypes: Finland: $\widehat{\sigma}, \mathrm{Ta}$ : Padasjoki, Vesijako strict nature reserve, 6806100: 3398800, 28.VIII.4.X.2004, Jakovlev leg. (MZH); đ, Ta: Lammi, Sudenpesänkangas, 6790212: 3403382, 28.IV.27.V.2004, Jakovlev leg. (METLA); ð, $K b$ : Ilomantsi, Kotavaara, 6998000: 3721000, 25.VIII.-2.IX.1998, Tietäväinen leg. (FRIP); ð’, Kb: Ilomantsi, Pirhu, 6993000: 3723000, 31.V.3.VI.1994, Polevoi leg. (FRIP).

Additional material examined. Finland: $\hat{\partial}$, Kb: Ilomantsi, Tapionaho, 6982000: 3729300, 19.-20.VIII.1993, Polevoi leg. (FRIP); 2 ठふ, same place, 19.-25.VIII.1994, Polevoi leg. (FRIP); ふै, $K b$ : Ilomantsi, Pirhu, 6993000: 3723000, 31.V.-3.VI.1994, Polevoi leg. (FRIP); 2 ô, $K b$ : Ilomantsi, Kotavaara, 6998000: 3721000, 25. VIII.-8.IX.1998, Tietäväinen leg. (FRIP); ô, Tb: Keuruu, Kummunmäki, 6908519: 3390002, 15.-29.V.2005, Penttinen leg. (JP); đ̂, Tb: Petäjävesi, Liisalanperä, 6911430: 3418872, 15.-29.V.2005, Penttinen leg. (JP); 10 ふ઼へ, $T b$ : Laukaa, Punavuori, 6928425: 3432699, 14.28.V.2005, Penttinen leg. (JP); Ô, Tb: Laukaa, Pöykynmäki, 6929388: 3434446, 14.-28.V. 2005, Penttinen leg. (JP); $4 \hat{\jmath} \hat{\jmath}, T b$ : Toivakka, Mansikkamäki, 6883081: 3450755, 14.-28.V. 2005, Penttinen leg. (JP); Ô, Tb: Toivakka, Rantomäki, 6898755: 3455372, 14.-28.V.2005, Penttinen leg. (JP); 2 ふふ઼, Tb: Toivakka, Vuorilampi, 6885707:3455772, 14.-28.V.2005, Penttinen leg. (JP); đ̃, Tb: Toivakka, Huhtalampi, 6883884: 3461804, 14.-28.V.2005, Penttinen leg. (NHMCF). Russian Karelia: $\hat{\jmath}, K b$ : Tolvajärvi， 29.VIII.-11.IX.1998， Tietäväinen leg. (FRIP); 6 えす, same place, 2.VI.-13.IX. 1999, Tietäväinen leg. (FRIP); đ̃, Kpoc: Kostomuksa strict nature reserve, Kamennoe lake, 8.12.VII.1996, Polevoi leg. (FRIP); ふૈ, Kon: Kivach strict nature reserve, 8.VIII.-6.IX.1990, Polevoi leg. (FRIP); 2 ふふ,, same place, 5.VII. 2001, Polevoi leg. (FRIP). Collecting sites are coniferous, Myrtillus-type, old-growth and managed forests, usually with a plenty of coarse and 
Fig. 1. Phronia avidoides sp. n., male terminalia. - a. Tergite IX and cerci. - b. Gonocoxite and gonostylus, ventral view. - c. Gonostylus, internal view. - d. Aedeagal complex, ventral view. Scale bar $0.1 \mathrm{~mm}$.
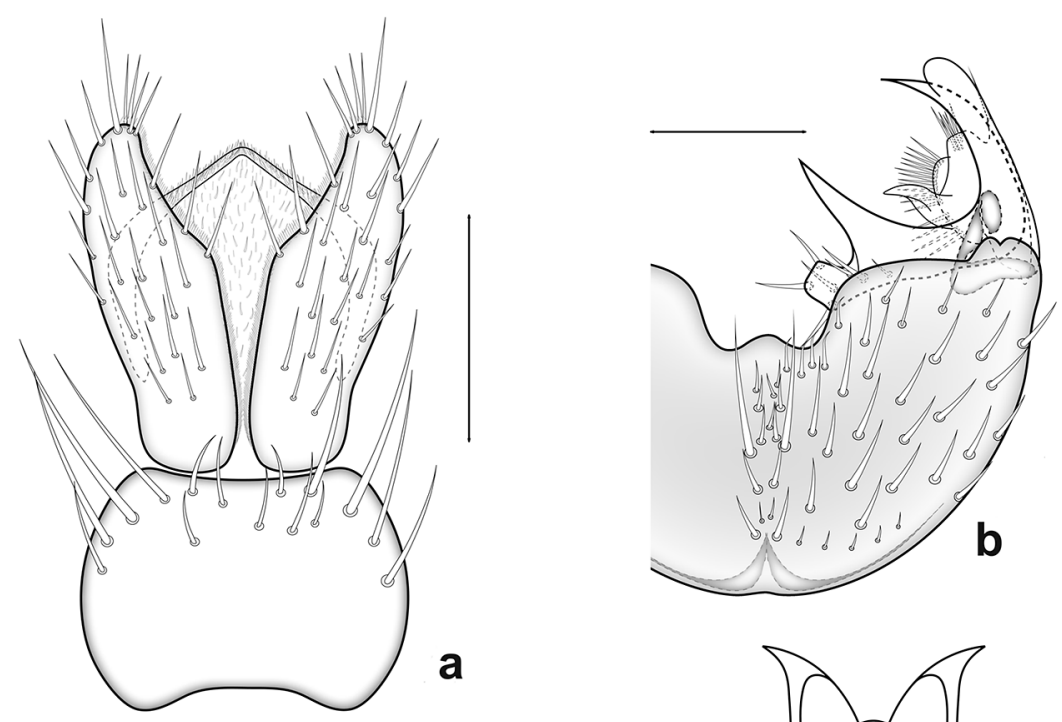

a

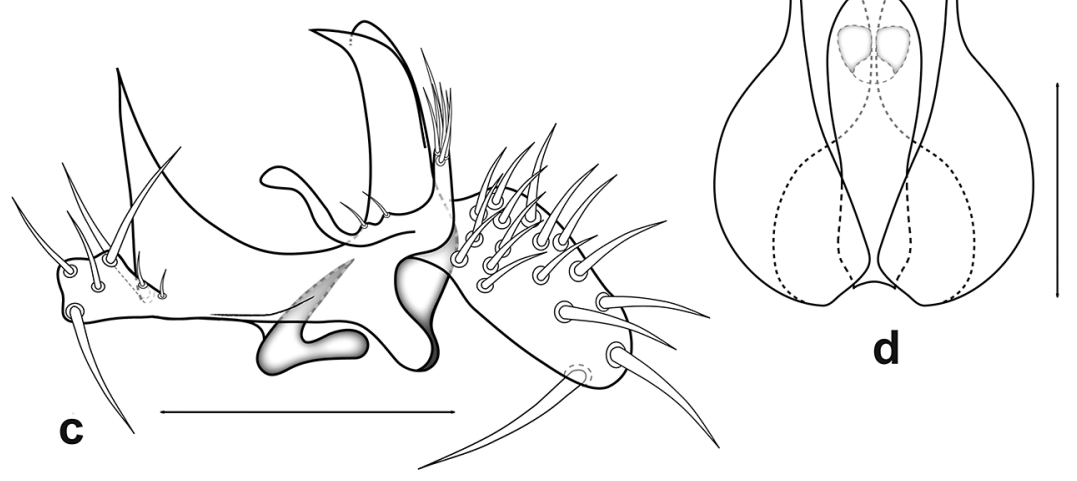

fine woody debris. In Pirhu ( $K b$ : Ilomantsi) specimens were collected in young forest on the abandoned agriculture lands.

Description. Male $(\mathrm{n}=5)$. Head dark brown. Mouthparts light brown, palp yellow, the third palpal segment slightly darkened at the apical half. Antenna uniformly dark brown, but in some specimens pedicel and the basal half of the first flagellomere lighter. Sixth flagellomere 1.5 times as long as wide.

Thorax. Mesonotum brown covered with dense yellowish hairs and scattered yellowish bristles. Pleuron brown. Pale specimens have more or less developed yellow humeral spots and yellowish propleuron. Propleuron with two strong pale bristles. Scutellum with four bristles, two strong ones medially and two smaller ones along the edges.

Wings. Wing length $2.3-2.7 \mathrm{~mm}$. Hyaline, veins yellow. Sc short, ending free. C very slightly extending beyond the tip of $\mathrm{R}_{5}$. Stem of M-fork 1.3 times as long as $t a$. The vein $t a$ with 3-5 macrotrichia. Haltere pale yellow.

Legs. Yellow, hind femur darkened apically and mid femur slightly infuscated on the very tip. Mid tibia with 4-5 $a, 3-4 d, 4-6 p$ and 5-7 $v$. Hind tibia with 7-8 $a, 7-10 d$ and $2-4 p$. Ratio of tibia to first tarsomere for front, mid and hind legs: $1.10-1.12$ [mean value 1,11 ]; 1.19-1.26 [1,23]; $1.52-1.56[1,53]$.

Abdomen. Brown, darkened caudally, tergites 2-3 with small to large yellowish lateral spots (obscure in darker specimens). Terminalia (Fig. 1) brown. The apicoventral margin of the gonocoxite have distinct, stepped emargination (occupying about $1 / 4$ of its total width) with almost abrupt lateral margins and small elevation in the bottom. Ventral lobe of gonostylus with elon- 


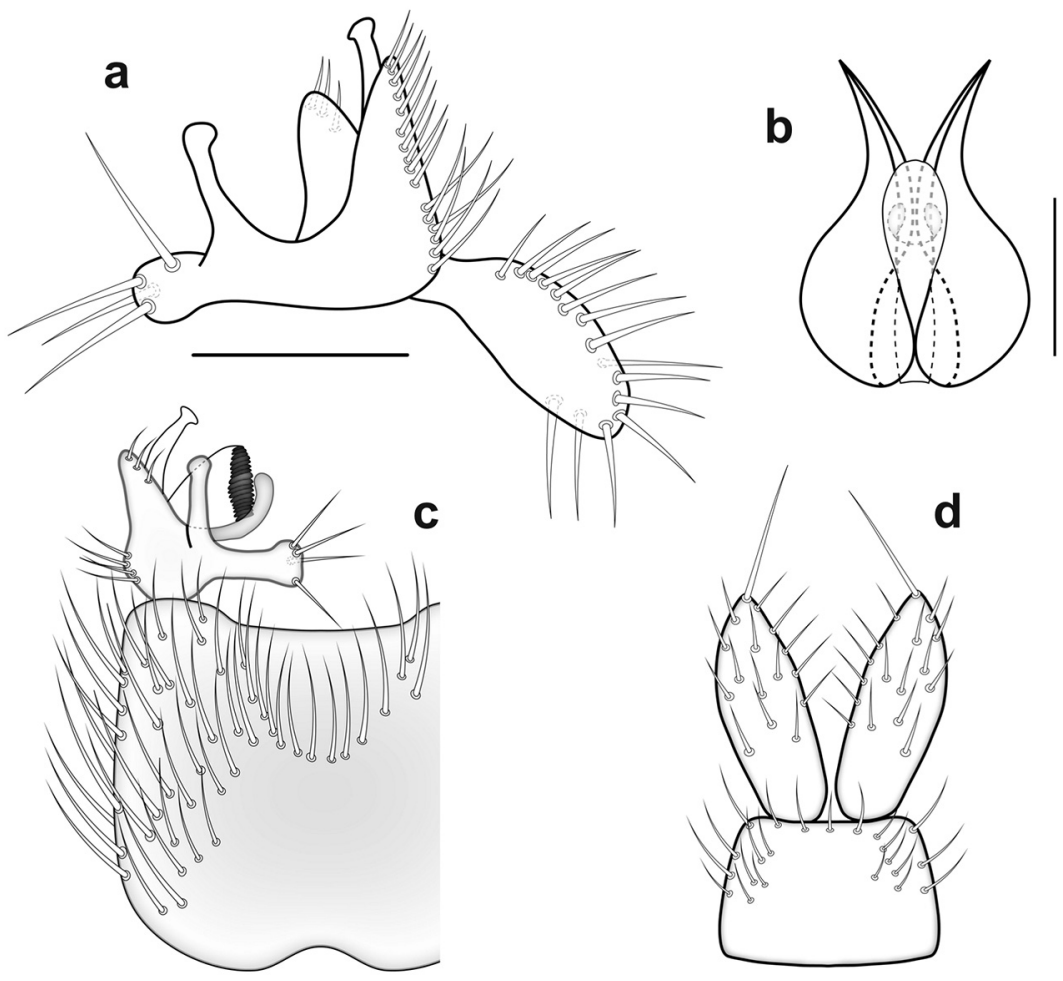

Fig. 2. Phronia avida Gagné,1975, male terminalia. - a. Gonostylus, external view. -b. Aedeagal complex, ventral view. - c. Gonocoxite and gonostylus, ventral view. - d. Tergite IX and cerci. Scale bar $0.1 \mathrm{~mm}$. gated basoventral projection bearing strong bristles and with two bare elongated processes. One of these processes, near the middle of the ventral lobe is apically pointed. The other one, near the caudal edge of the ventral lobe has an apex forked into two branches of which one is apically pointed and the other rounded.

Female. Unknown.

Larval biology. Unknown.

Etymology: The species' name indicates its resemblance to $P$. avida Gagné, 1975.

Diagnostic characters. The new species, $P$. avidoides, resembles $P$. avida, but differs clearly by the following characters of the male terminalia. The apicoventral margin of the gonocoxite is narrowly and deeply excised in $P$. avidoides, while it is wide and shallowly concave in $P$. avida (Fig. 1b, 2c). The two elongated, bare processes on the ventral lobe of the gonostylus have pointed apices in $P$. avidoides (Fig. 1c), while they are rounded and apically spatulated in $P$. avida (Fig. 2a). In $P$. avidoides the apex of the paramere is wide, abruptly pointed (Fig.1d), while it is more elongated and stretched in P. avida (Fig. 2b). The inner edge of the cercus is slightly excised along the apical third in P. avidoides (Fig.1a), while it is almost straight, smoothly pointed apically in P. avida (Fig. 2d). Another related species is P. strenua Winnertz, 1863, which clearly differs in having a weakly developed basoventral process of the ventral lobe of gonostylus (see Gagné 1975, p. 313, fig. 78; Zaitzev 2003, p. 324, fig. 97, 4).

\subsection{Phronia fennica sp. n. (Fig. 3)}

Type material. Holotype $\widehat{\delta}$ : Finland, Ta: Padasjoki, Vesijako strict nature reserve, 6806100: 3398800, 27.VII.-27.VIII.2004, Jakovlev leg. $(\mathrm{MZH})$. Collecting locality is a Norway spruce dominated Myrtillus-type old-growth forest. Paratypes: Finland: $\hat{\jmath}$, Ta: Lammi, Lapinjärvi, 6793704: 3397492, 28.VIII.-4.X.2004, Jakovlev leg. (MZH); đ̂, Ta: Lammi, Leipäsuonaho 6789920: 3395865, 28.VIII.-4.X.2004, Jakovlev leg. (METLA). Collecting areas are clear-cuts with retention trees treated with prescribed burning.

Additional material examined. Finland: đo Ta: Lammi, Kotinen, 6794400: 3396400, reared from 
Fig. 3. Phronia fennica sp. n., male terminalia. -a. Aedeagal complex, ventral view. - b. Gonostylus, internal view. -c. Gonocoxite and gonostylus, ventral view. $-d$. Tergite IX and cerci. Scale bar $0.1 \mathrm{~mm}$.

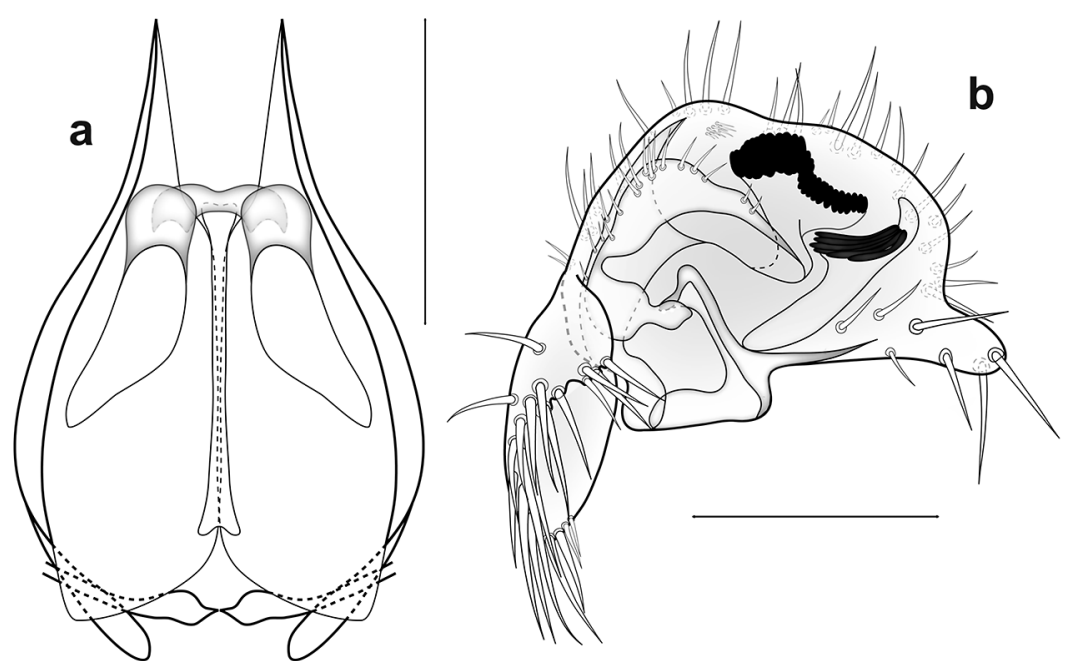

C

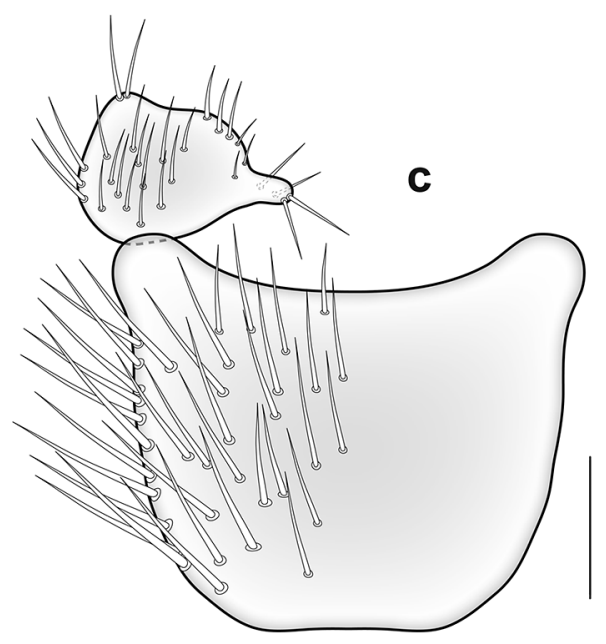

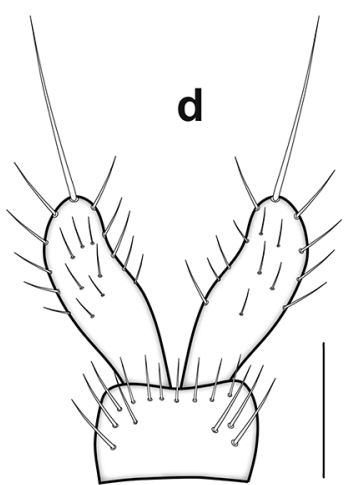

decaying spruce log, 27.VII.2005, emergence 27.IX.2005, Jakovlev leg. (METLA); $\widehat{T} \mathrm{Ta}$ : Lammi, Niemisjärvi, 6791324: 3394263, 27.IV.27.V.2004, Jakovlev leg. (METLA). Russian Karelia: ${ }^{\lambda}$, Kpoc: Kostomuksha strict nature reserve, $10 \mathrm{~km}$ SSW of Kostomuksha, 23.-26. VIII.1995, Polevoi leg. (FRIP). Collecting localities are old-growth Myrtillus and Vaccinium-type coniferous forests.

Description. Male $(\mathrm{n}=5)$. Head brown, Mouthparts and palp light brown. Antenna brown, scape, pedicel and the basal half of the first flagellomere light brown to pale. Sixth flagellomere twice as long as wide.

Thorax. Mesonotum brown, covered with fine dense yellowish hairs and strong scattered yellowish bristles. Pale specimens with yellow lateral spots and propleuron. Pleuron brown. Scutellum with four bristles, two strong ones medially and two smaller ones along the edges. Propleuron with two strong, pale bristles.

Legs. Pale yellow to dark brown, hind femur and tibia sometimes slightly darkened apically. Mid tibia with 3-5 $a, 2-3 d, 3 p$ and $7 v$. Hind tibia with $6 a, 7-8 d$ and $3 p$. Ratio of tibia to first tarsomere of front, mid and hind legs: 1.03-1.09 [mean value 1,06]; 1.23-1.32 [1,27]; 1.47-1.53 [1,51].

Wings. Wing length $2.5-3 \mathrm{~mm}$. Wings hyaline, yellowish, veins yellow. Sc short, ending free. $C$ very slightly extending beyond the tip $R_{5}$. Stem of M-fork 1.2 times as long as $t a$. The vein ta with 3-5 macrotrichia. Haltere pale yellow.

Abdomen. Brown, darkened caudally. Ter- 


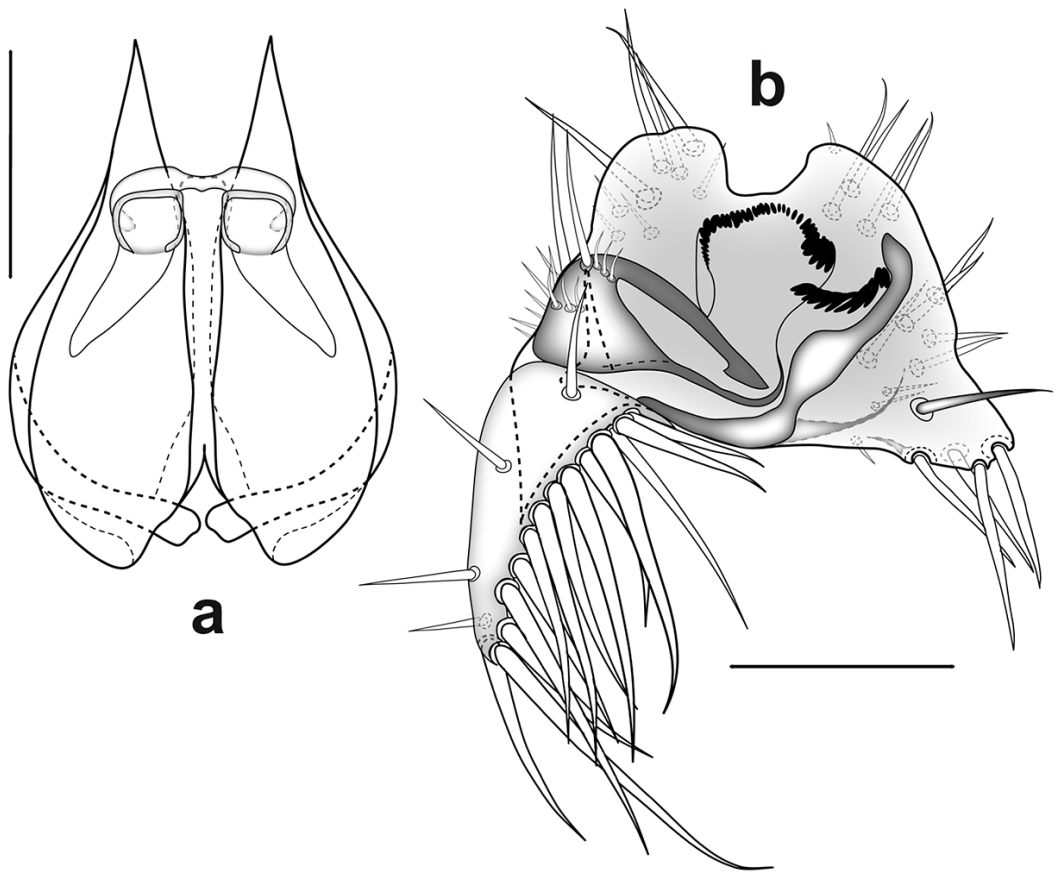

Fig. 4. Phronia subsilvatica Hackman, 1970, male terminalia. - a. Aedeagal complex, ventral view. - b. Gonostylus, internal view. Scale bar $0.1 \mathrm{~mm}$. gites 1-3 with big, yellowish lateral spots. Terminalia (Fig. 3) brown. Apicoventral margin of gonocoxite almost straight. Ventral lobe of gonostylus humpbacked with short basoventral projection bearing 2 apical bristles and several smaller bristles near the apex.

Female. Unknown.

Larval biology. One male has been reared from decaying spruce $\log$ bearing fruiting bodies of Antrodia serialis.

Etymology. The species' name indicates the first records being from Finland.

Diagnostic characters. The new species most closely resembles $P$. subsilvatica Hackman, but differs by the almost straight apical edge of the ventral lobe of gonostylus (Fig. 3b), which has a distinct rectangular excavation in $P$. subsilvatica (Fig. 4b). Other related species are $P$. petulans Dziedzicki, 1889 and P. cupida Gagné, 1975. P. petulans differs by more rounded ventral lobe of the gonostylus, presence of small curved spines near the apical edge on inner surface of the gonostylus, and different structure of basal parts of the aedeagal complex (Fig. 5). P. cupida has the same type of aedeagal complex, but the ventral lobe of gonostylus has a distinct apical depression (though not so distinctly excavated as $P$. subsilvatica) and some strong elongated setae along the apical edge (see Gagné 1975, p. 313, figs 74-77).

\section{Other related species of Phronia studied}

\subsection{Phronia avida Gagné, 1975 (Fig. 2)}

Material examined. $\widehat{N}$, (Paratype, Smithsonian Institution, National Museum of Natural History, Washington, USA, dry-pinned, terminalia preserved as glycerine preparation in small vial on the same pin as the rest of the body), USA, Alaska, Matanuska, rotary trap, 5.-16.VI.1944, J.C. Chamberlin leg.

\subsection{Phronia subsilvatica Hackman, 1970 (Fig. 4)}

Material examined. Holotype đo (No. 14254, pinned with terminalia in balsam preparation on slide) Finland, Ks: Kuusamo, Kiutaköngäs 21.VIII.1964, Tuomikoski \& Mikkola leg. (MZH). Paratype $\widehat{\delta}\left(\mathrm{N}^{-}\right.$14248, pinned with ter- 
Fig. 5. Phronia petulans Dziedzicki, 1889, male terminalia. - a. Aedeagal complex, ventral view. - b. Gonostylus, internal view. Scale bar $0.1 \mathrm{~mm}$.

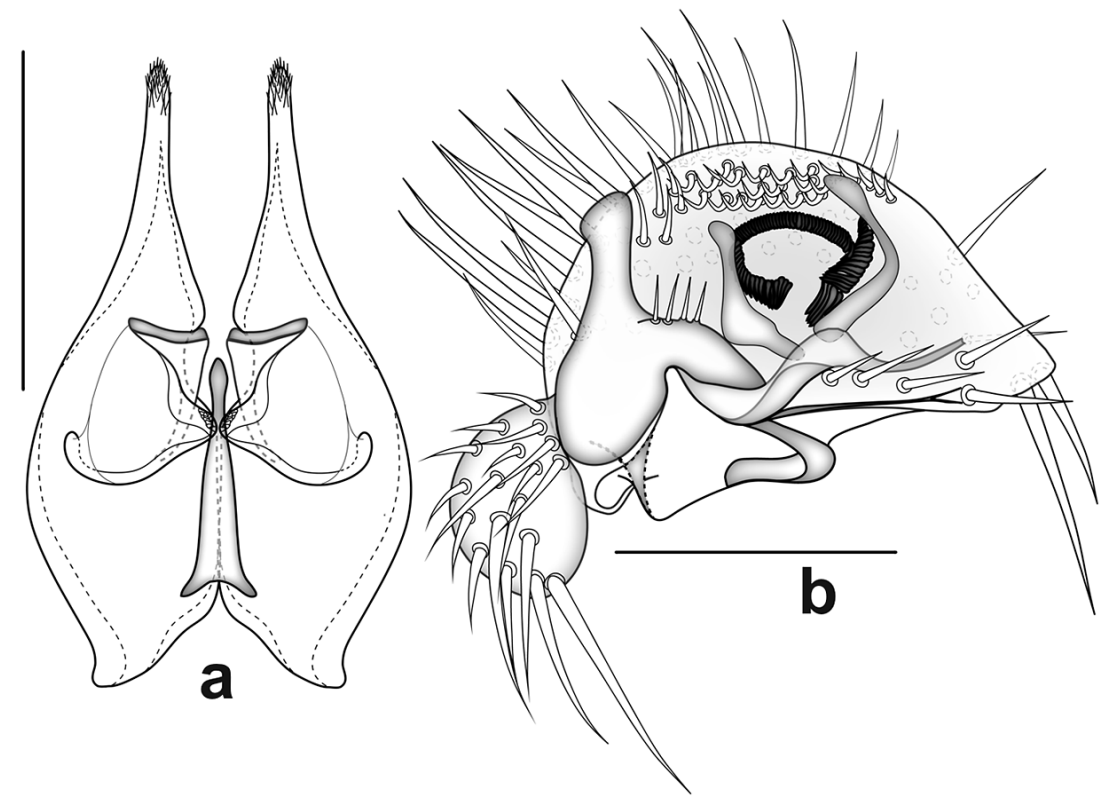

minalia in balsam preparation on slide), $K s$ : Kuusamo, Juuma 21.VIII.1964, Tuomikoski \& Mikkola leg. (MZH): đo (dry-pinned, terminalia preserved as glycerine preparation in small vial on the same pin as the rest of the body). Russian Karelia: Kon: Kivach strict nature reserve, a herbrich spruce dominated forest with aspen, 27.V. 2003, Polevoi leg. (FRIP).

\subsection{Phronia petulans Dziedzicki, 1889 (Fig. 5)}

Since Hackman (1970) has provided the most detailed figures of the male terminalia of $P$. petulans, we follow his interpretation of this species. However, Hackman (1980) marked P. petulans with a question mark in the checklist of the Finnish Diptera.

Material examined. Finland: $\widehat{O}, N$ : Nordsjö, 10.V.1963, Tuomikoski leg. (MZH, pinned with terminalia in balsam preparation on slide); $\widehat{\sigma} \mathrm{Kb}$ : Koli, 18.V.1964, Tuomikoski leg. (MZH, marked with ?, pinned with terminalia in balsam preparation on slide, hardly visible); Russian Karelia: $\widehat{\partial}$, Kon, Kivach strict nature reserve, a herb-rich spruce dominated forest with aspen, 31.V.-

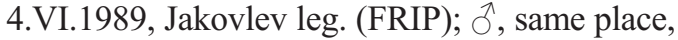
sweep netting 5.VII.2001, Polevoi leg. (FRIP).
Acknowledgements. Authors are grateful to Dr. F. Christian Thompson and Dr. David G. Furth, Smithsonian Institution, National Museum of Natural History, Department of Entomology, Washington, USA for the loan of type material on Phronia avida Gagné. We are indebted to Dr. Jostein Kjærandsen (Zoological Museum of Lund University, Sweden), Jouni Penttinen (University of Jyväskylä, Finland) for the help during preparation of the manuscript and to the referees for the valuable comments on the manuscript. This paper is a part of the project "Finnish fungus gnats (Diptera, Mycetophilidae, etc.) and log midges (Diptera, Porricondylinae): faunistics, habitat requirements and threat status". The financial support from the Finnish Ministry of Environment is hereby acknowledged.

\section{References}

Bechev, D. 2000: World distribution of the genera of fungus gnats (Diptera: Sciaroidea, excluding Sciaridae). - Studia Dipterol. 7 (2): 543-552.

Chandler, P.J. 1978: Associations with plants. Fungi. — In: Stubbs, A \& Chandler, P.I. (eds), A Dipterist's Handbook. Amateur Entomologist 15:199-211. The Amateur Entomologist's Society, Middlesex. 255 pp.

Chandler, P.J. 1992: A review of the British Phronia Winnertz and Trichonta Winnertz (Dipt., Mycetophilidae). - Entomologist's Monthly Magazine, 128: 237-254.

Chandler, P. J. 2005: Fauna Europaea: Mycetophilidae. In: de Jong, H. (ed.), Fauna Europaea: Diptera, Nematocera. Fauna Europaea, version 1.2. [www document] URL http://www.faunaeur.org (accessed 7 March 2005). 
Chandler, P. \& Ribeiro, E. 1995: The Sciaroidea (Diptera) (excluding Sciaridae) of the Atlantic Islands (Canary Islands, Madeira and the Azores). - Boletim Mus. Municip. Funchal (Hist.Nat). Suppl. 3: 1-110.

Dziedzicki, H. 1889: Revue des espèces européennes du genre Phronia Winnertz avec la description des deux genres nouveaux: Macrobrachius et Megophthalmidia. - Horae Soc. Ent. Ross. 23: 404-532.

Gagné, R. J. 1975: A revision of the Nearctic species of the genus Phronia (Diptera, Mycetophilidae). - Trans. Amer. Entomol. Soc. 101: 227-318.

Gammelmo, Ø. \& Søli, G. E. E. 2006: Norwegian fungus gnats of the family Mycetophilidae (Diptera, Nematocera). — Norw. J. Entomol. 53: 57-69.

Hackman, W. 1970: New species of the genus Phronia Winnertz (Diptera, Mycetophilidae) from Eastern Fennoscandia and notes on the synonymies in this genus. - Notul. Entomol. 50: 41-60.

Hackman, W. 1980: A check list of the Finnish Diptera I. Nematocera and Brachycera (s.str.). - Notul. Entomol. 60: 17-48.

Heikinheimo, O. \& Raatikainen, M. 1971: The recording of locations of biological finds in Finland. - Ann. Entomol. Fennici 37 (1a): 1-27.

Jakovlev J. 1994: Palaearctic Diptera associated with fungi and myxomycetes. - Karelian Research Centre, Russian Academy of Sciences, Petrozavodsk. 127p. [In Russian with English abstract].

Jakovlev, J., Kjærandsen, J. \& Polevoi, A. 2006: Seventy species of fungus gnats new to Finland (Diptera: Mycetophilidae). - Sahlbergia 11: 22-39

Kjærandsen, J., Hedmark, K., Kurina, O., Polevoi, A., Økland, B. \& Götmark, F. 2007: Annotated checklist of fungus gnats from Sweden (Diptera: Bolitophilidae, Diadocidiidae, Ditomyiidae, Keroplatidae and Mycetophilidae). - Insect Syst. Evol. Suppl. 65: 1-128.

Kurina, O. 2003: Notes on fungus gnats from the Lemmenlaakso area in southern Finland, including six species new to the Finnish list (Diptera: Sciaroidea excl.Sciaridae). - Sahlbergia 8: 84-88.

Lundström, C. 1906. Beiträge zur Kenntnis der Dipteren Finlands. 1. Mycetophilidae. - Acta Soc. Fauna Flora Fenn. 29: 1-50.
Lundström, C. 1909: Beiträge zur Kenntnis der Dipteren Finnland. 4 Supplement: Mycetophilidae. - Acta Soc. Fauna Flora Fenn. 32: 1-63.

Lundström, C. 1911: Neue oder wenig bekannte Europäische Mycetophiliden. - Ann. Mus. Natio. Hung. 9: 390-419.

Lundström, C. 1914: Beiträge zur Kenntnis der Dipteren Finlands. IX. Supplement 3. Mycetophilidae. - Acta Soc. Fauna Flora Fenn. 39: 1-26.

Plassmann, E. 1977: Revision der europäishen Arten der Pilzmückengattung Phronia (Diptera: Mycetophilidae). - Deutsch. Entomol. Zeitschr. N.F. 24: 305 344.

Plassmann, E. 1999: Neue bayerische und schwedishe Pilzmücken (Diptera, Nematocera, Sciaroidea, Mycetophilidae). — Mitt. Münch. Entomol. Ges. 89: 5-9.

Polevoi, A. V. 1995: Fungus gnats (Diptera, Mycetophilidae) in Pirhu and Tapionaho (Ilomantsi, Finland). In: Hokkanen, T. J. \& Ieshko, E. (eds), Karelian biosphere reserve studies: 159-166. North Karelian Biosphere Reserve, Joensuu.

Polevoi, A.V. 2000: Fungus gnats (Diptera: Bolitophilidae, Ditomyiidae, Keroplatidae, Diadocidiidae, Mycetophilidae) in Karelia. - Karelian Research Centre, Russian Academy of Sciences, Petrozavodsk. 84 pp. [In Russian with English abstract].

Polevoi, A. V., Jakovlev, J. \& Zaitzev, A. I. 2006: Fungus gnats (Bolitophilidae, Keroplatidae and Mycetophilidae) new to Finland. - Entomol. Fennica 17: 161169.

Søli, G. E. E. 1997: The adult morphology of Mycetophilidae (s.str.), with a tentative phylogeny of the family (Diptera, Sciaroidea). — Entomol. Scand. Suppl. 50: 5-55.

Zaitzev, A. I. 2003: Fungus gnats (Diptera, Sciaroidea) of the fauna of Russia and adjacent regions. Part 2. - Int. J. Dipterol. Res. 14: 77-386.

Zaitzev, A. \& Polevoi, A. 1995: New species of fungus gnats (Diptera, Mycetophilidae) from the Kivach Nature Reserve, Russian Karelia. — Entomol. Fennica 6: 185-195. 